\title{
The Socio-Economic Importance of Forest Exploitation and Environmental Impacts of the Consequent Deforestation in Dimako, East Region of Cameroon
}

\author{
${ }^{1}$ Dr. Robert Njilla Mengnjo Ngalim, ${ }^{2}$ Djou Edgard \\ ${ }^{1}$ Lecturer / Consultant on Specified Assignment, Department of Development Studies, \\ Pan African Institute for Development - West Africa, Cameroon. \\ ${ }^{2}$ Master of Science (M.Sc.) Student, Department of Geography, University of Buea, Cameroon \\ njillamn@yahoo.com,edgarddjou2015@gmail.com
}

\begin{abstract}
The proliferation of forest degradation is of major concern to the human population because it affects and impacts their direct environment on a daily basis. The main focus of this study was to investigate the socio-economic importance of forest exploitation and the environmental impacts of the consequent deforestation in Dimako and its environs. The methodology used was based on primary data obtained from the study area through the use of a questionnaire to identify the various ways forest exploitation is benefiting the population and how deforestation has impacted their environment. The study also made use of published information by the council authorities on land use activities in Dimako. The findings revealed that there are several socioeconomic benefits of forest exploitation in Dimako. Also, the environmental impacts of the consequent deforestation in Dimako, which have severe negative repercussions on the human population, have been revealed. There has been a gradual and consistent decrease in the rainforest of Dimako as well as its biological diversity (both flora and fauna). This deforestation is mainly caused by the activities of logging companies extracting wood from the forest, and individual inhabitants in the quest to exploit forest resources for their livelihood. The effects have been consistent forest degradation and consequently deforestation. This study therefore recommended planning and implementation of sustainable forest survey and monitoring the conservation practices which are in line with sustainable management of the forest.
\end{abstract}

Keywords: Socio-Economic Importance, Forest Exploitation, Environmental Impacts, Deforestation, Degradation, Dimako, East Region, Cameroon.

\section{INTRODUCTION}

Since the creation of the earth, humans have always lived in harmony with the natural environment due to the fact that it was from there that his life depended entirely (Dindi, 2011). Thus, there existed a mutual relationship between man and his environment. The forest provided humans with food, shelter and clothing and in return humans had the duty to protect the forest from disappearing. This agreement was respected for many centuries until the early 1970s. The world today is facing food insecurity due to pressure from demographic explosion (Lambi, 2010; Global Deforestation, 2006; Angelson and Kaimonitz, 1999). This has forced the population to increase the area under cultivation by destroying the forest to cultivate more food to feed the ever growing human population. The forested area is also being converted to settlement areas for the ever increasing human population. This results to deforestation at an alarming rate. Brown (2002) and FAO (2012) define a forest as any piece of land covered by vegetation which is dominated by trees, shrubs and many species capable of producing products other than agricultural products. The forest is therefore the planet's largest and most important terrestrial ecosystem. It is the largest reservoir consisting of plants, insects, birds and animals (Mesmin and Fogwe, 2009; FAO, 2005; 2003). According to FAO (2011; 2006), a forest is a minimum area of land of $0.05-1.0$ hectare with tree crown cover (or equivalent stocking levels) of more than $10-30 \%$ with trees having the potential to reach a minimum height of $2-5$ metres at maturity.

Deforestation is a global phenomenon which is noticed in all parts of the globe and is referred to by many forest statisticians as the excessive cutting down of trees by humans without replacement (Chakravarty, et al., 2012; Butler, 2006; 1994). Deforestation refers to the loss of forest cover, land 
that is permanently converted from forest to agriculture, golf courses, cattle pasture, and settlements. This is supported by the Food and Agricultural Organisation (FAO) $(2010 ; 2006 ; 2000 ; 1997)$ who went further to define tropical deforestation as "change of forest with depletion of trees, crown cover to less than $10 \%$. The depletion of forest to tree crown greater than $10 \%$ but less than $40 \%$ is considered forest degradation". The FAO went further to explain that logging most often falls under the category of forest degradation and thus is not included in deforestation statistics. The rates and causes of deforestation vary from region to region across the globe. In 2009, two-thirds of the world's forests were in the ten top countries including Russia, Brazil, Canada, the United States, China, Australia, Congo, Indonesia, Peru and India respectively (FAO, 2011; 2010). The world's annual rate of deforestation is estimated at 13.7 million hectares and only half of this area is compensated by new forest growth or afforestation activities (FAO, 2006; van Kooten and Bulte, 2000; Barraclough and Ghimire, 2000).

According to the FAO $(2012$; 2006) Reports, Africa is suffering from deforestation at twice the world's rate of about $40 \%$. The report also arrogates that deforestation has already wiped out roughly $90 \%$ of West Africa's originally forested area. Deforestation is accelerating in Central Africa. According to the FAO (1997), Africa lost the highest percentage of tropical forest of any continent during the 1990s and early 2000s due to excessive forest exploitation which in most cases was not accompanied by sustainable measures like reafforestation and effective measures to regulate forestry activities. Also, according to FAO (2000; 1997), only 22.8\% of West Africa's moist forest remains, much of which is degraded and Nigeria has lost about $81 \%$ of its old growth forest in just 15 years (1990 - 2005) (FAO, 2007; 2006). Massive deforestation threatens food security in some African countries. One factor contributing to the continent's high rate of deforestation is the over-dependency of about $90 \%$ of its population on wood as a major source of energy for heating and cooking.

In Cameroon, deforestation is occurring all over the country at an alarming rate from the North to the South and from the East to the West due to human-induced factors. For the past years, Cameroon has lost most of its vegetal cover of about $13.4 \%$ between 1990 and 2005 due to poor forestry management by the government, the forestry companies and the actions of illegal logging practices by unscrupulous people in their quest for economic gains at the detriment of the environment (Delénè, et al., 2009; Mesmin et al., 2009; Brown, 2002; Neba, 1999, MINEF, 1995). So, some measures have to be taken to stop or drastically reduce the phenomenon. Human activities with the quest for better livelihood are the principal driving forces which have unfortunately led to deforestation and perturbation of forestland in Dimako (Cabinet NECT, 2009; CANADEI, 2010; Brown, 2002). This area has been subjected to industrial logging for more than half a century which has led to the creation of the road for the installation of agricultural exploitation at the expense of the existing forest. Deforestation for agricultural purposes has been further stimulated by the presence of the principal road linking Abong-Mbang to Bertoua through Dimako. Therefore, pressure on forest land in this area greatly increased between 1972 and 1980 due to the delocalisation of the saw mill out of the district. This brought poverty and unemployment in an area where forest exploitation has for long dominated agriculture. The misery of the inhabitants was later aggravated with the devaluation of the franc CFA in 1993 (Cabinet NECT, 2009; CANADEI, 2010).

\section{The Problem, OBJeCtives AND Hypotheses}

Since the early stages of creation of humanity, the human population has always been living in harmony with the forest due to the fact that it was from there that the survival of humans depended. It was from there that man extracted raw materials to provide basic needs such as food, shelter and clothing (Sunderlin et al., 2005). However, due to human evolution, mankind began exploiting the forest excessively without replacement, as a result of this egoistic or egocentric behaviour of mankind wherein his main focus was only on economic gains derived from the sale of forest products, humankind forgot about environmental protection. Thus, resulting to the phenomenon of deforestation which in the long run coupled with dramatic climatic caprices has severe implications on the local population (FAO, 2012; 2011; 2006; Chakravarty, et al., 2012). This is the case with the population of Dimako in the East Region of Cameroon that is affected negatively by deforestation. The inhabitants of Dimako are very closely linked to the forest and its resources (MINEF, 1995). The forest ecosystem provides many products and services to the local population. For instance, wood, berries and mushrooms, bush meat, non-timber forest products and other recreational services. More recently, recognisable benefits of the forest include various environmental services such as carbon 
sequestration, watersheds protection, erosion control and maintaining biodiversity (Chakravarty, et al., 2012). The sub-division is only about $28 \mathrm{~km}$ from Bertoua, an urban centre with a high demand for wood for construction, furniture and other household uses. The commercialisation of wood is a lucrative business that has encouraged not only over-exploitation but illegal exploitation of trees in this area by some unscrupulous individuals who are out to make economic gain from forest products. The forest in this district has thus been subjected to clandestine and uncontrolled exploitation of the flora and fauna species, coupled with poor tillage practise such as the use of bush fires during the process of slash-and-burn farming. All these processes have led to the modification of the vegetation profile which is gradually being transformed into savannah.

The low level of education, poverty of the population and ignorance on behalf of the local community have drastically contributed to rampant deforestation in this locality coupled with poor management by the authorities in change of the forest. The numerous tree species of economic importance which are threatened by extinction include iroko, sapelle, ebony and iron wood. The above facts show how forest conservation is vital for the well being of mankind on the planet earth. If the above-mentioned problems are not addressed with vigour, then the population of this ecological zone might become "environmental refugees" in the future. The main objective of this study therefore was to investigate the socio-economic importance of forest exploitation and the environmental impacts of the consequent deforestation in Dimako, East Region of Cameroon. Specifically, the study made an appraisal of forest exploitation and utilisation; examined the causes and drivers of deforestation; examined the socio-economic and environmental impacts of deforestation in Dimako and proposed recommendations for sustainable exploitation of forest resources in order to reduce the rate of deforestation in Dimako. The study hypothesised that deforestation is as a result of population growth, poverty and unemployment rate in Dimako. Rapid deforestation in Dimako is a function of population growth and unsustainable socio-economic activities.

\section{The STUdy AREA}

\subsection{Location of the Study Area}

Dimako is located in the East Region of Cameroon and lies between latitudes $4^{\circ} 23 \mathrm{~N}$ and $4^{\circ} 38 \mathrm{~N}$ north of the equator and longitudes $13^{\circ} 34 \mathrm{E}$ and $13^{\circ} 56 \mathrm{E}$ east of the Greenwich Meridian (Map 1). The subdivision covers a total surface area of $750 \mathrm{~km}^{2}$. It is bordered to the east by Mbang and Ndemnam in Kadey Division, to the north by Bertoua I and Bertoua II sub-divisions, to the west by Ndiang subdivision in the Lom and Djerem Division and to the south by Doume in Upper Nyong Division. Dimako is crossed from north to south by the Number 10 national road linking Yaounde the nation's capital to Bertoua. Dimako is located some $26 \mathrm{~km}$ from Bertoua and by a secondary road linking Abong-Mbang Lambou Batouri in its eastern part at a distance of $18 \mathrm{~km}$. The district is about $75 \mathrm{kms}$ away from Abong Mbang the headquarters of the Upper Nyong Division and about 310kms from Yaounde, the nation's capital (Commune de Dimako, 2010). Dimako comprises of 30 villages and neighbourhoods sub-divided into five sectors as follows:

- Pol Sector: Tahate, Bangossi, Ngombol, Akono, Nkolmeyan, Grand Pol, Sumoyong, Tonkonne, Little Pol, Nkolbikon, Mayos;

- Forest Sector: Djandjia, Kouen, Toungneto, Lessou, Mbang;

- Road Sector: Kandala, Ngunda, Nkoumadjap;

- Savannah Area: Small Ngolambole, Ngolambele, Baktala, Longtimbi;

- Dimako Centre: Kpwegue, Source, God Knows (Dieu Connait), Tombo, Ayene, Camp Nord, Mokolo, Beal.

\section{RESEARCH Methodology}

Research methodology involves the ways used to obtain information within the study area. It can be done by using the following methods; data collection techniques and data analysis and presentation.

Primary data were collected through field study which involved surveying the forest area to observe the activities taking place within the forests, such as the felling of trees, harvesting of non-timber forest products, human activities taking place within the forest area and the environmental impacts 
such as forest degradation. Also, a survey was conducted in the local markets to observe the marketing of non timber forest products. This technique proved valuable in collecting vital data which could not easily be obtained using other sources of data collection.

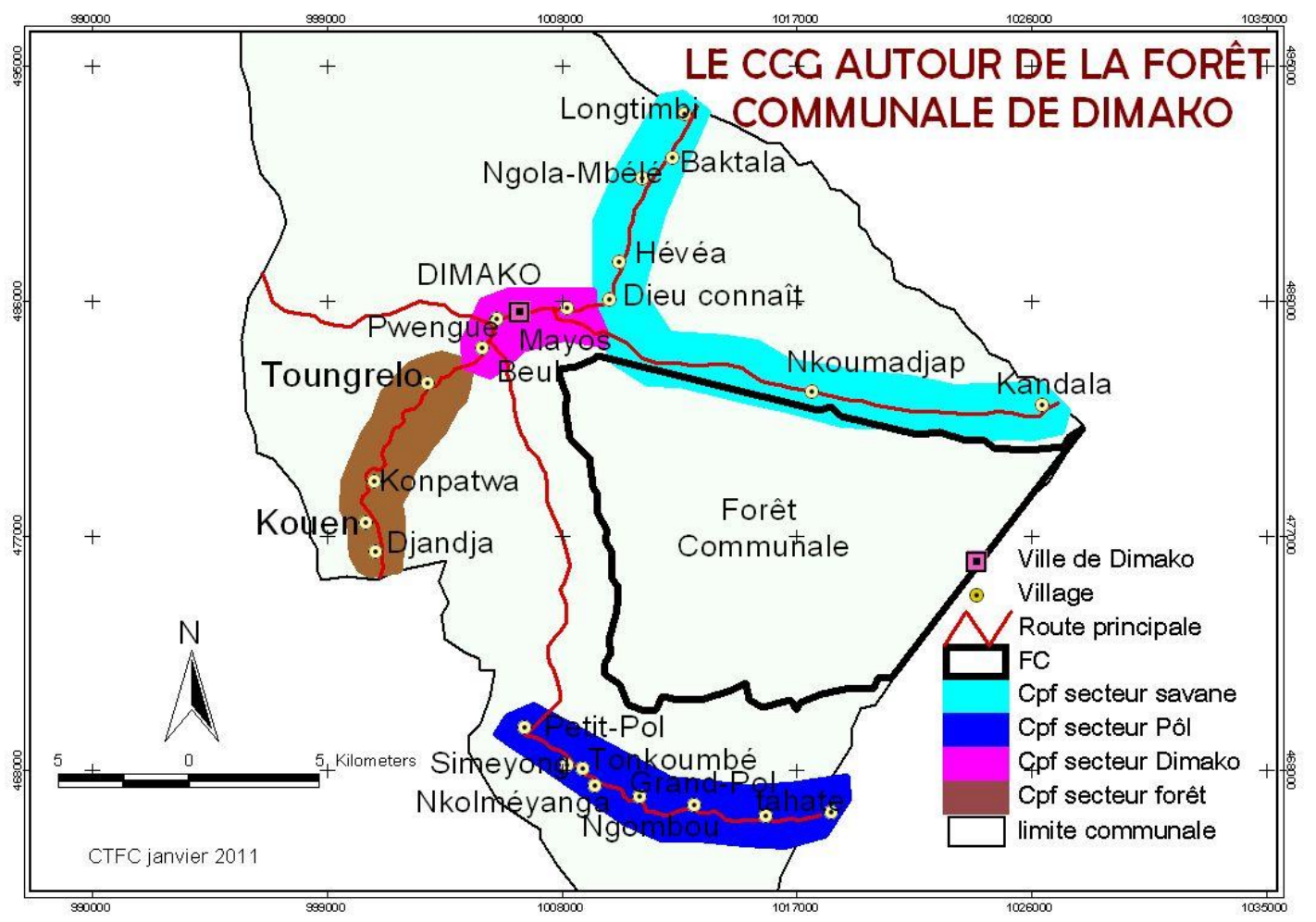

Map 1. The Location of Dimako Sub-division in the East Region of Cameroon

Source: Commune de Dimako (2015)

Concerning the administration of questionnaires, a total of 260 questionnaires were administered (and 252 returned) to the various stakeholders involved in forest exploitation and marketing in Dimako. Questions targeted the exploitation and utilisation of the forest resources such as timber and nontimber products, their marketing, the drivers of forest degradation and deforestation in Dimako, the environmental impacts of deforestation and mitigation strategies. This source of information was corroborated with interviews with various authorities and stakeholders involved in the exploitation of forest and non-timber forest products in Dimako.

The secondary sources of data entailed the use of textbooks, journals, magazines, websites from the internet, radio and televisions, as well as conferences. Materials and information from existing published and unpublished works such as dissertations in public and private libraries (such as the University of Buea Library), related to the topic were also consulted. Maps showing the location and forest sites of Dimako were equally obtained from the Dimako Council.

Data obtained were analysed qualitatively and quantitatively. Frequency tables were used to represent data in tabular form starting with percentages. Tables were equally used to describe the variables and attributes of the nature of forest exploitation in Dimako sub-division, and the environmental impacts to the inhabitants of Dimako. The analysed data were presented in the form of descriptive writing, tables, photographs and graphical representations for easy understanding and to answer the study objectives.

\section{Conceptual Framework}

\subsection{The Deforestation Cycle and its Negative Environmental Impacts}

This theory postulates that deforestation occurs as a complete cycle coupled with its negative environmental impacts (Figure 1). The forest serves as a protective shell to the ground where trees help to protect the surface from direct violent climatic phenomena such as intense rainfall which in the absence of trees will lead to the leaching of the soil, causing soil erosion. Therefore, when an area is subjected to deforestation, it leads to an increase in the impact of rain droplets, thus having negative 
environmental impacts. Also, deforestation leads to a reduction in interception of rain water, reduction in infiltration rate, increase in surface runoff, increase in surface erosion and gully formation, increase in soil detachment, channel aggradation and/or degradation and bank erosion. These processes are aggravated due to the absence or destruction of the vegetation which acts as protecting agent against the elements of weather and climate. From this perspective, all the above-mentioned negative impacts are present in Dimako and have greatly impacted the environment which in turn affects the life of the inhabitants of this locality in all domains or activities including farming and harvesting of non-timber forest products.

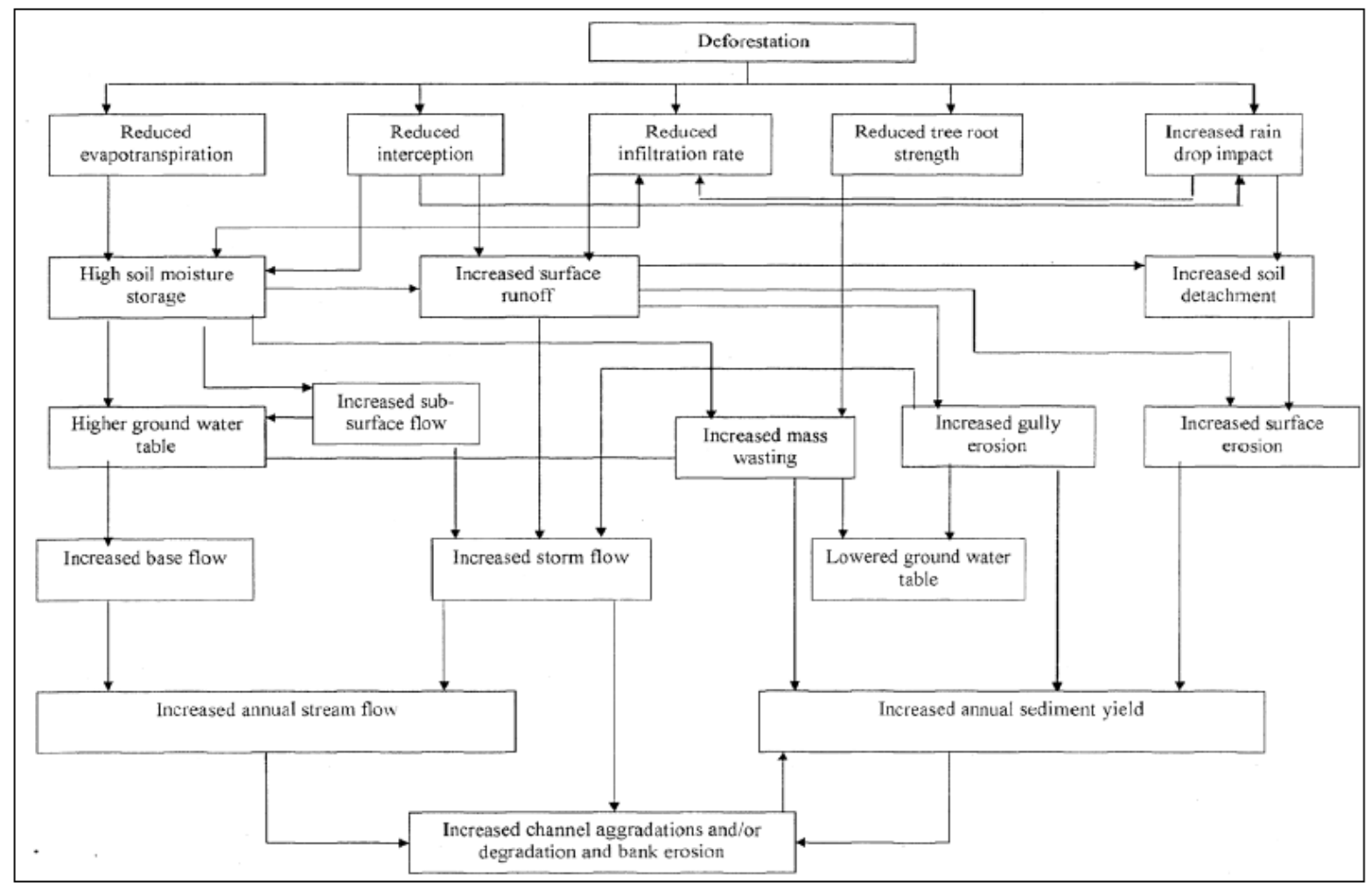

Figure 1. The Deforestation Cycle and Its negative Environmental Impacts

Source: Lambi (2010: 63)

\subsection{The Concept of Population, Exploitation and Sustainable Management}

This concept was propounded by Alain Marcout in 2002. It proves that human activities like agriculture and grazing contribute to forest loss which are driven by factors that have little or nothing to do with the local population growth rate. He went ahead to show the diversity of population-forest sustainable linkages and/or dynamics. The concept also shows that there is a significant relationship between forest exploitation and human population. Population density is selected as an independent variable of the forest cover from a static point of view, and an inverse correlation exists (Figure 2). Therefore, when the need for food and other agricultural products increases in predominantly agricultural societies, it is necessary either to increase the output (productivity) of land currently under cultivation, or to increase the cultivated area. Quite often, however, the option of an increase in yields is difficult to achieve - because of adverse natural conditions, or because it would require costly inputs such as fertilizers, pesticides and irrigation; or because not enough labour can be mobilized due to the competition of other occupations. In those cases, more land must be cleared. This is often done at the expense of forests or wooded cover. This happens in particular in the system of shifting cultivation, which involves allowing part of the available land to fallow - and grow natural wooded cover - between two periods of cultivation. A fatal imbalance occurs when "the shifting cultivators, whose cyclic movements are sustainable when spread widely, find their population increasing and their land area dwindling. They are being forced to shorten rotations, which can lead to permanent nutrient loss and degradation to non-forest ecosystems" (Chakravarty, et al., 2012; FAO, 2012). Shifting cultivation is commonly estimated to have caused about two thirds of the global deforestation in recent decades. 
From Figure 2, land is put into various uses through the destruction of the forest. Forests are cleared down for agriculture (farming and grazing), fuel wood and above all some areas conserved for future use (sustainability).

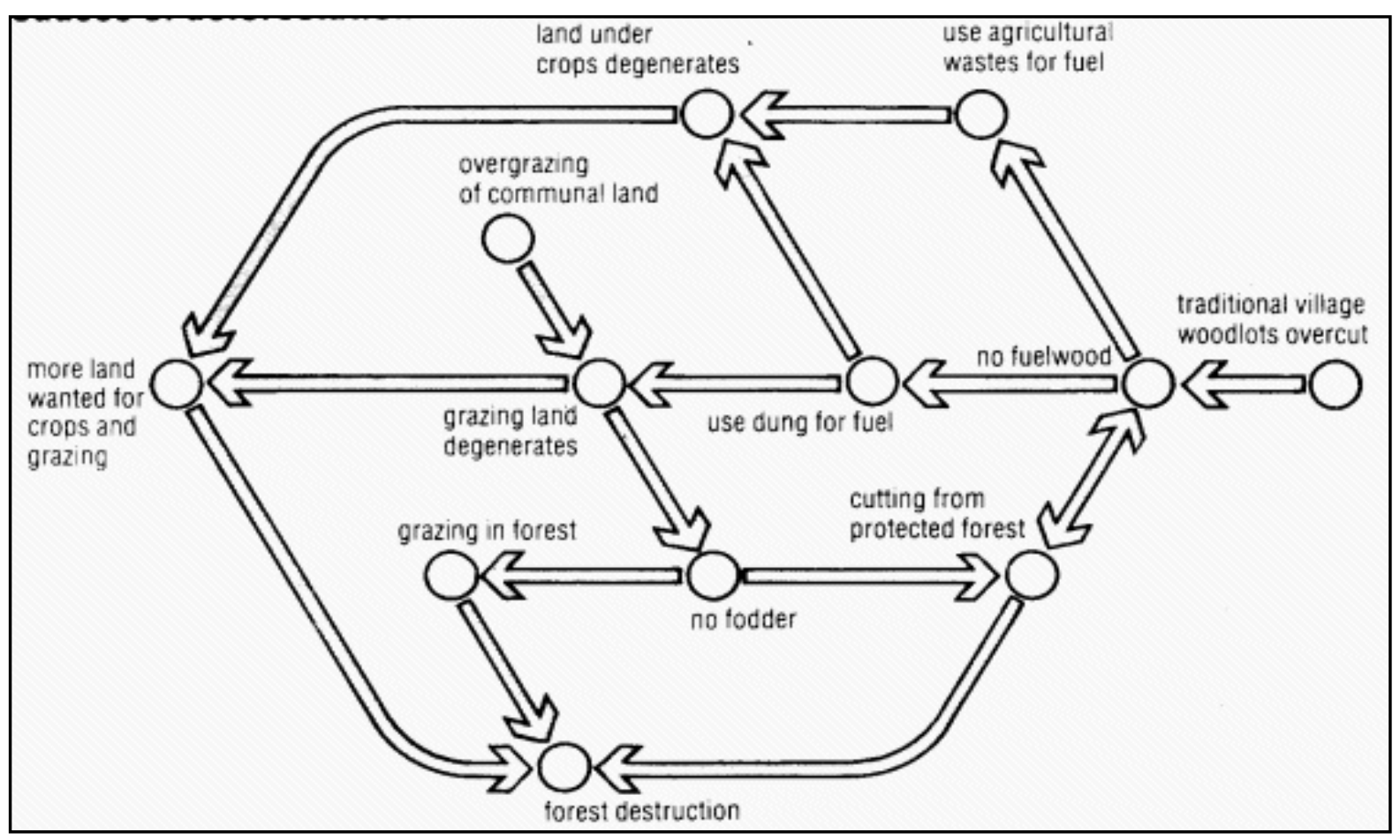

Figure 2. A Schematic Representation of a Common Pattern of Activities and Outcomes in a Forest Ecosystem

Source: FAO (1989:5) cited in Marcout (2002)

From this concept, population represents livelihood; gathering and harvesting represent forest exploitation. Human activities have a direct impact on the environment. Agriculture which is the dominant occupation in this locality has greatly contributed to environmental degradation. It could be attributed to poor farming methods in Dimako mostly shifting cultivation which is very detrimental to the environment. The rapid population increase of Dimako in recent years normally implies an increase in the supply of food to feed the ever increasing population. This implies an expansion of existing farmland and the creation of new ones. This will result to a vast and rapid destruction of the forest which will lead to an increase in farmland as a positive factor but leads to environmental degradation and all its related negative consequences. So, human activities have greatly contributed to environmental degradation most notably deforestation in Dimako.

\section{Findings AND DiscuSSIONS}

\subsection{Presentation of Demographic Data of the Respondents}

Sex of Respondents: Findings revealed that $72 \%$ of the respondents were males while $28 \%$ were females. This means that the males are dominant and highly involved in forest exploitation as against females. Being a highly physical activity which requires human force, men are in the best position to perform such tasks.

Age Range of Respondents: The findings revealed that 52\% of the population were between 31 to 45 years, followed by those between 16 to 30 years (30.7\%), while the least were those above 46 years of age (17.3\%). From this perspective, about $83 \%$ of the respondents are made up of youths and adults who constitute the active population and from this respect they are those engaged in activities such as farming, tapping of palm wine and forest exploitation, both artisanal and modern. They thus constitute the bulk of those involved in forest exploitation due to their strength and ability to work while those above 46 years are no more very active and can no longer withstand the work in forest exploitation.

Educational Level of Respondents: The study also investigated if the level of education of the population had negative repercussions on the forest. From the results, Dimako being a rural area has a very low educational level as most rural and backward areas in Cameroon, due to lack of educational infrastructures and appropriate decentralisation of the educational system. Findings revealed that a 
majority of the population has not gone above the first school leaving certificate level, and thus their awareness on forest degradation and management is very minimal.

Marital Status of Respondents: Results illustrate that the highest proportion of marital status were those married (67.3\%), followed by those who were single (23.1\%), the divorced (1.9\%) while others which included the widows and widowers constituted 1.9\%. From this perspective, the highest proportion of married people implies that the population gets married at a very young age. So, early marriages in Dimako can clearly explain the high birth rate which implies the demand for more land for habitation and agriculture, thus leading to forest degradation and deforestation.

Number of Persons per Household: Since the population number is a direct factor leading to forest degradation and deforestation, the study sought to investigate if the number of persons per household has a direct impact on forest degradation. Findings revealed that $63.5 \%$ had above four persons per household. This high number per household is justified by the high birth rate as a result of early marriages and the early and high reproduction of girls in this locality. Dimako being a rural area where agriculture is dominant, having many children will imply abundant labour force highly demanded in agriculture, thus all these parameters contribute to accelerated forest degradation.

\subsection{Spatial Extent of the Forest in Dimako Sub Division}

The Dimako sub division, which engulfs 30 villages, is predominantly made up of evergreen forests. Since the introduction of the sawmill by the French through the SFID Company, this forest has witnessed excessive and intense destruction. This forest exploitation company is heavily involved in industrial wood exploitation. Due to this massive exploitation, the density of the forest has drastically reduced. Today, there exist only few villages that have a dense forest cover including Djandja, Kouen, Tongrelo, Lessou and Mbang (Map 2).

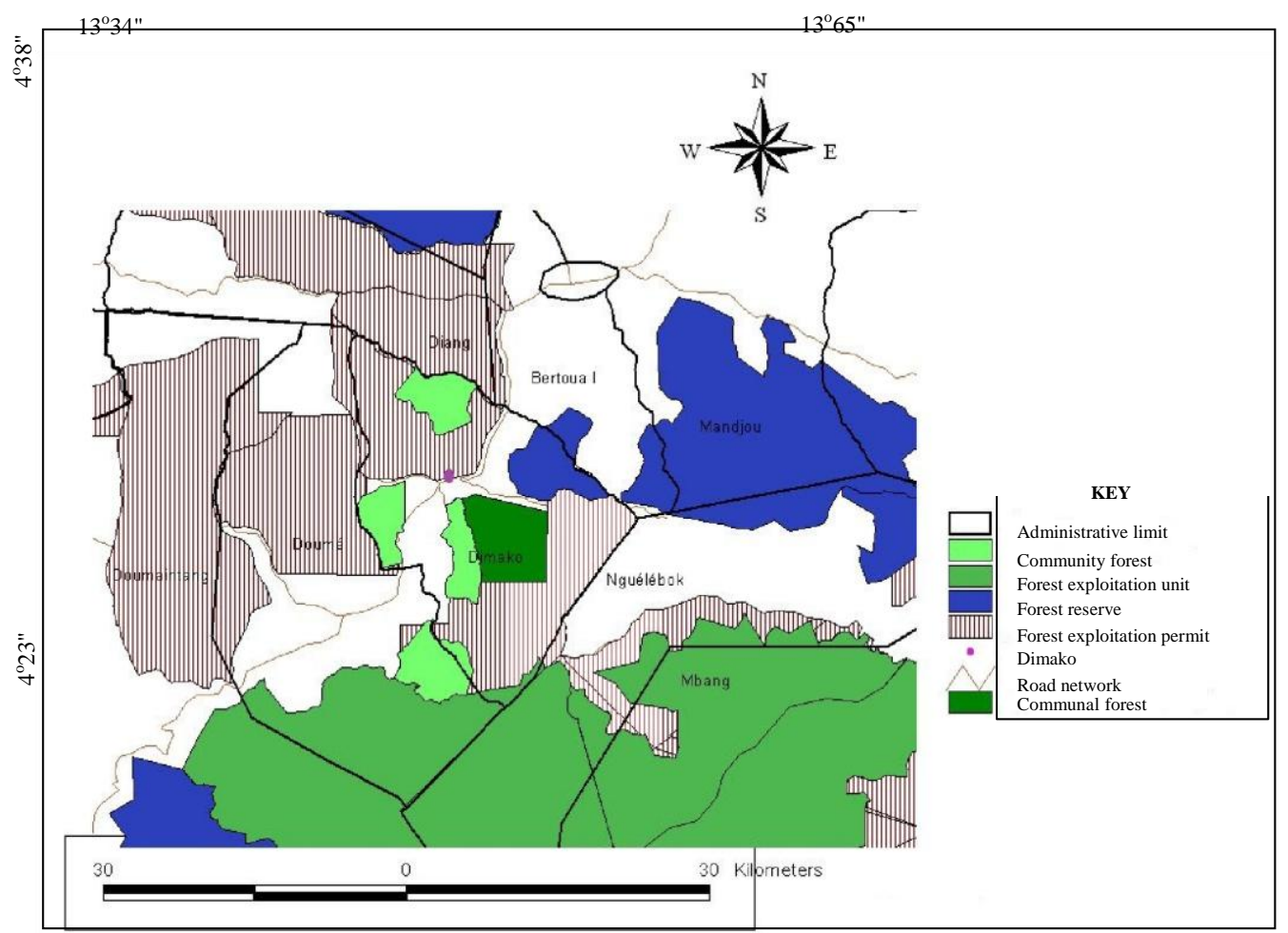

Map 2. Spatial Location of the Forest in the District of Dimako and its Environs

Source: CANADEI (2010)

As a result, many exploitation companies have now relocated to other areas like Mbang, Mindourou where the forest is still very abundant. The forest in Dimako will practically disappear despite the various strategies put in place to reduce the devastating effect of deforestation which has serious environmental repercussions on the inhabitants of Dimako municipality and its environs. From Map 2, it is therefore clear that the spatial distribution of the forest in Dimako is uneven, whereby some areas that formerly had a thick forest canopy no longer have any forest. As a strategy, the government in its efforts to restore the forest in Dimako has created a communal forest reserve. 


\section{Dr. Robert Njilla Mengnjo Ngalim \& Djou Edgard}

\subsection{Socio-Economic Importance of Forest Resources Exploited in Dimako Sub Division}

It was necessary to ask the inhabitants of Dimako if forest exploitation really benefited them or contributed to the development of this locality. From the survey, it was evident without any doubt that the answer was "yes". This is justified by many parameters as presented in the following paragraphs. For the onset, the survey revealed that $90.4 \%$ of the respondents said 'yes' against $9.6 \%$ who said 'no'. From these contrasting views, it is clear that forest exploitation largely contributed to the development of Dimako in all aspects. Dimako is merely a small locality which many never knew from the onset except with the establishment of the sawmill in the 1970s. Its population increased tremendously due to the ever increasing influx of people in search of employment that the sawmill offered. So, forest exploitation is the key to the development of Dimako and it has thus gained international reputation. Also, the inhabitants of Dimako gained a lot from forest exploitation in that it led to infrastructural development and provision of social amenities such as schools, hospitals, public administration, public taps and enormous job opportunities. This has helped to reduce unemployment in the whole East Region and Dimako in particular. So, it is convenient to conclude that forest exploitation has greatly contributed to the development of Dimako in various domains, one of which is the exploitation of species. There are many species of plants and animals exploited from the forests of Dimako. Table 1 presents the principal forest products collected, their origin and parts used.

Table1. Principal Forest Products in Dimako Sub Division

\begin{tabular}{|c|c|c|c|}
\hline $\begin{array}{c}\text { Vernacular / local } \\
\text { name }\end{array}$ & Scientific name & $\begin{array}{c}\begin{array}{c}\text { Exploited for } \\
\text { wood }\end{array} \\
\end{array}$ & Part used \\
\hline Moabi & Baillonella toxisperma & $\sqrt{ }$ & Pulp, grain, bark, latex \\
\hline Ayous & Triplochiton scleroxylon & $\sqrt{ }$ & Specific caterpillars \\
\hline Sapelli & Entrandrophragmacy lindricum & $\sqrt{ }$ & Specific caterpillars \\
\hline Padouk & Pterocarpus spp & $\sqrt{ }$ & Barks \\
\hline Essessang & Richnodendron hendelotii & $\sqrt{ }$ & Grain \\
\hline Emien & Alstonia congolensis & $\sqrt{ }$ & Bark \\
\hline Tali & Erytrophleumivo rensis & $\sqrt{ }$ & Bark \\
\hline Yellow Moambe & Enathia chloranta & $\sqrt{ }$ & Bark \\
\hline Bush mangoes & Irvangia gabonensis & $\mathrm{x}$ & Fruit, seeds \\
\hline Colanuts & Cola accuminata & $\mathrm{X}$ & Seeds \\
\hline Akpa & Tetrapleura tetraptera & $\mathrm{x}$ & The pod \\
\hline Ndimba & Afrostyrax lepidophyllus & $\mathrm{x}$ & Grain, bark \\
\hline Raffia & Raphia spp & $\mathrm{x}$ & Shoots, rachis (Bamboo) \\
\hline Palm tree & Elaeis guineensis & $\mathrm{x}$ & Nuts \\
\hline Cane & Ancystrophyllum spp nontige & $\mathrm{x}$ & Stem \\
\hline Yam & Dioscorea spp & $\mathrm{x}$ & Tubers \\
\hline Koko Eru & Gnetum africanum & $\mathrm{x}$ & Leaves \\
\hline Voacanga & Voacanga Africana (non fruit latex) & $\mathrm{x}$ & Fruit, latex \\
\hline Bitter cola & Garcinia cola & $\mathrm{x}$ & seeds \\
\hline
\end{tabular}

Products underlined are those of high economic potentials $\sqrt{ }=$ Exploited; $x=$ Not exploited

Source: Societe Forestiere et Industruelle de la Doume (SFID, 2015)

As said above, it is evident that forest exploitation has greatly contributed to the development of Dimako. Educationally, it has led to the construction of schools in Dimako and its neighbourhoods to take care of the ever increasing demands for education. Thus, it has made many parents to send their children to school and this has contributed in reducing the high illiteracy level in this region. It can therefore be concluded that forest exploitation has made educational infrastructures more accessible to a majority of the people in Dimako and its environs. In the domain of health, the sanitary condition of the people has greatly improved through the opening of hospitals and health centres to palliate or alleviate the ever increasing demands in terms of medical care. Also, it has led to infrastructural development though the construction of some minor roads though not tarred but which greatly help to connect the different villages in Dimako as well as link it to the various exploitation sites. Socially, due to the fact that many are employed and gain a salary or wages, the people could now improve their living conditions thereby boosting their standard of living. Therefore, economically, forest exploitation in Dimako has led to the employment of thousands of Cameroonian in the country as a whole and in Dimako sub division in particular. Politically, forest exploitation has made Dimako to 
change its status administratively, that is, it moved from a district to a sub division. This has made the people to benefit all that constitute a change in status administratively such as infrastructural development through the construction of public administrative services and other social infrastructures, and the setting up of many other public services. Therefore without doubt it can be clearly affirmed that thanks to forest exploitation, Dimako has gained autonomy and prestige and has become what it is today. These findings are in line with those of Lopez and Stanley (2004) who identified the riches of the forests in Africa and its role in livelihood sustenance. So, forest exploitation has greatly contributed to the development of Dimako and its environs. However, the over-reliance and over-exploitation of the forest in Dimako has not been without its problems. As such, there has been a heavy toll on the forest through degradation and deforestation as examined below.

\section{Forest Degradation in Dimako Sub Division}

Since the forest has undergone many damages in Dimako, the study therefore investigated the predominant causes of forest degradation in Dimako. From the findings, it is clear that industrial wood exploitation which constitutes about 53\% is the predominant cause of forest degradation. This is very true due to the fact that industrial wood exploitation implies massive cutting down of trees over very large expands of land as compared to wood collection which represents only $5.8 \%$. This is mainly because the quantity of wood collected by all the people for their daily uses is very minimal but on another dimension wood collection becomes a problem when it is collected in large quantities for sale in the neighbouring urban centres like in Bertoua where there is high demand. Lumbering is very detrimental to the forest and it constitutes about $19.2 \%$ while farming which is the principal activity here constitutes only $17.3 \%$. Medicinal plant collection only represents $3.9 \%$. Thus, from this view, it is clear that if not of industrial wood exploitation, the forest of Dimako would not have witnessed excessive degradation and deforestation. The above findings are supported by those of Bjorn (2001), Bannon and Collier (2003) and William (2003) who variedly identified the processes and causes of forest degradation and deforestation at the global level.

\section{Factors Contributing to the Degradation of the Forest in Dimako}

Over the past decades, vast areas of the forest in Dimako has been damaged as a result of population growth and related expanding agriculture and commercial farming. Intensive exploitation of forest resources through logging, hunting, extraction of medicinal plants; fuel wood and charcoal exploitation are amongst the major factors responsible for forest degradation in Dimako sub division. It is therefore quite important to have a broad knowledge of the factors that contribute to the degradation of the forest in Dimako. This is so important because these should be at the base of restoration, prevention policies and strategies, if we really want to ensure the effective and sustainable management of the forest in Dimako. These factors range from socio-cultural, environmental, economic and political, as discussed below.

\subsection{Socio-Cultural Factors}

Human being generally need forest resources for food, wood, and medicine and forest land for agriculture, industrialisation and settlement. This has led to the exploitation of non-timber forest products as a way of life in Dimako (Plate 1). The intensive over-exploitation of forest resources in Dimako has caused the shrinking of the forest and its resources. The shift of behavioural pattern from the love for greenery to the love for concrete is another main factor involved in the degradation of the forests in Dimako. In Cameroon, like in many African countries, forest governance mechanisms do not efficiently integrate the communities and other stakeholders such as non-governmental organisations and private exploiters in the conception and implementation of policies and strategies for the conservation of forest resources. Therefore, poor capacity building and legal education to the communities and non-profit and profit-making actors have contributed a lot to slow down the responses to the efforts being put in place to achieve a sustainable exploitation and conservation of forests and biodiversity. The lack of transparency in monitoring of forestry activities as the case of Dimako cannot favour our vision for a sustainable forestry. This is coupled with the ignorance or improper implementation of laws and regulations by the various stakeholders to aggravate the situation. All these have greatly contributed to the fast and intensive deforestation and degradation of the forest in Dimako sub division and its neighbourhoods. 

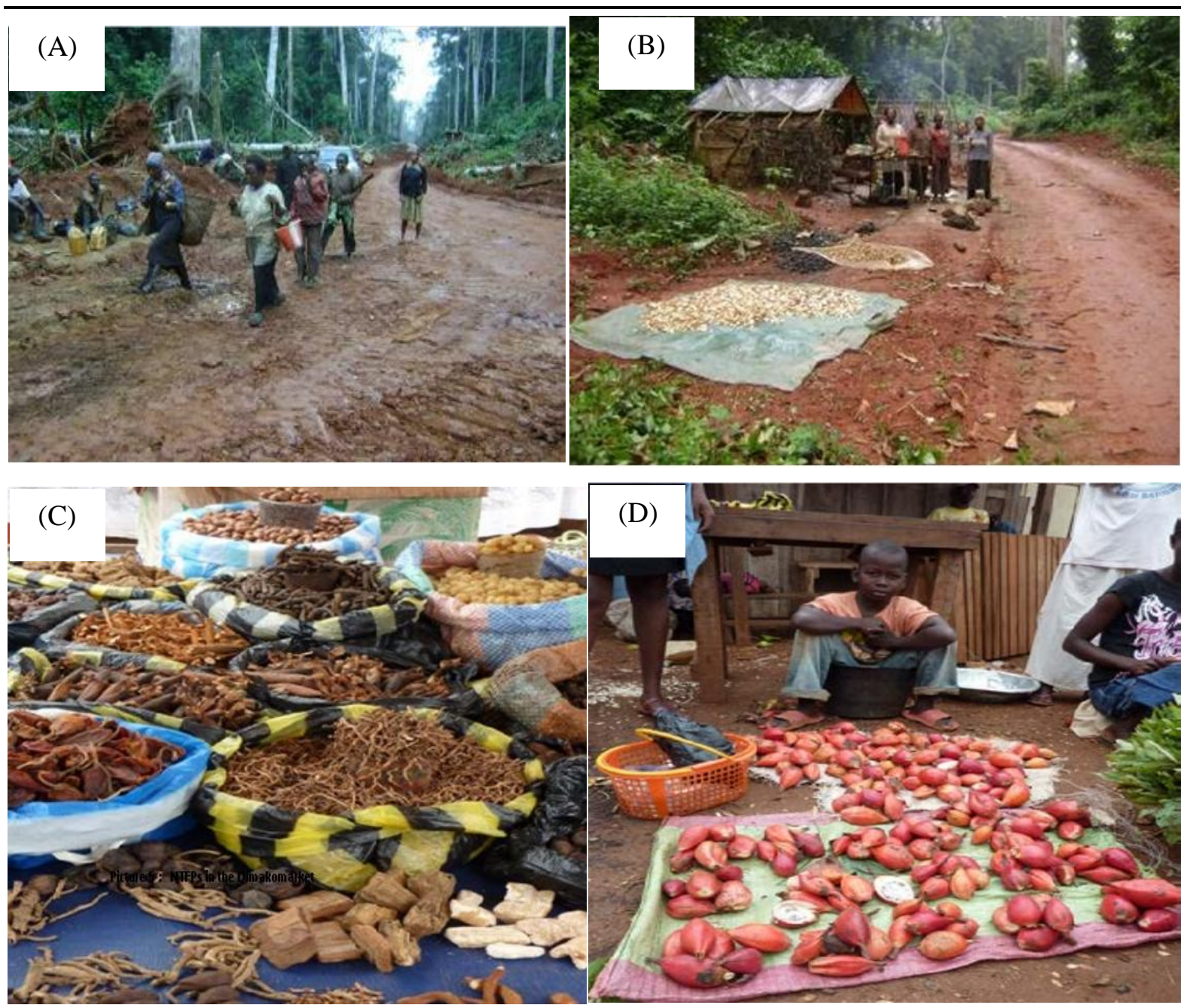

Plate 1. Exploitation and Marketing of Non-Timber Forest Products in Dimako (A) inhabitants going to the forest, (B) sun drying of bush mangoes (C) various species of spices harvested from the forest, (D) Thaumatococcus danielli fruits harvested from the forest in Dimako

Source: Divisional Delegation of Forestry, Dimako /Field work (2015)

\subsection{Logging}

Logging is one of the main factors of the degradation of the tropical forest in Dimako. Since the establishment of the saw mills in the early 1970s, there has been an increase and intensive forest exploitation (Plate 2). The massive exploitation by logging companies has greatly damaged the forest of Dimako, thus causing severe destruction of the environment. This implies that logging when practised intensively and in an unsustainable manner greatly contributes to the degradation of the forest in Dimako and consequently to deforestation. Another dimension of the problem is when roads are constructed by the logging companies for the evacuation of timber. Huge expanses of land are destroyed in order for a road to pass, sometimes to evacuate only a few trees (Plates 1A \&B, Plate 2E).

\subsection{Population Growth}

There exist a direct relationship between population increase and increase in demand for our planetary resources. This means that the more the population increases, the more we need land for settlement and for agricultural activities. Thus, more forest resources are exploited for food and furniture. Consequently, more pressure is placed on our forests. The rapid population in Dimako is as a result of early marriages and a high reproduction rate faced by the people in this locality. From this, it is clearly understood that as the number of people increases rapidly, so too the pressure of the population on the forests and forest resources. This then leads to degradation of the forests and consequently deforestation. According to Chakravarty et al., (2012), an increase in the world's population to about 5.2 billion, and today to 7 billion (FAO, 2012; 2006) has raised the demand for certain basic necessities. Since third world countries cannot meet up with recent technologies to 
The Socio-Economic Importance of Forest Exploitation and Environmental Impacts of the Consequent Deforestation in Dimako, East Region of Cameroon

sustain the ever increasing population, an exploitation activity, like forest and non-timber forest products, has remained the main stay of the rural inhabitants of this locality. This has led to severe degradation and consequently deforestation in Dimako sub division.
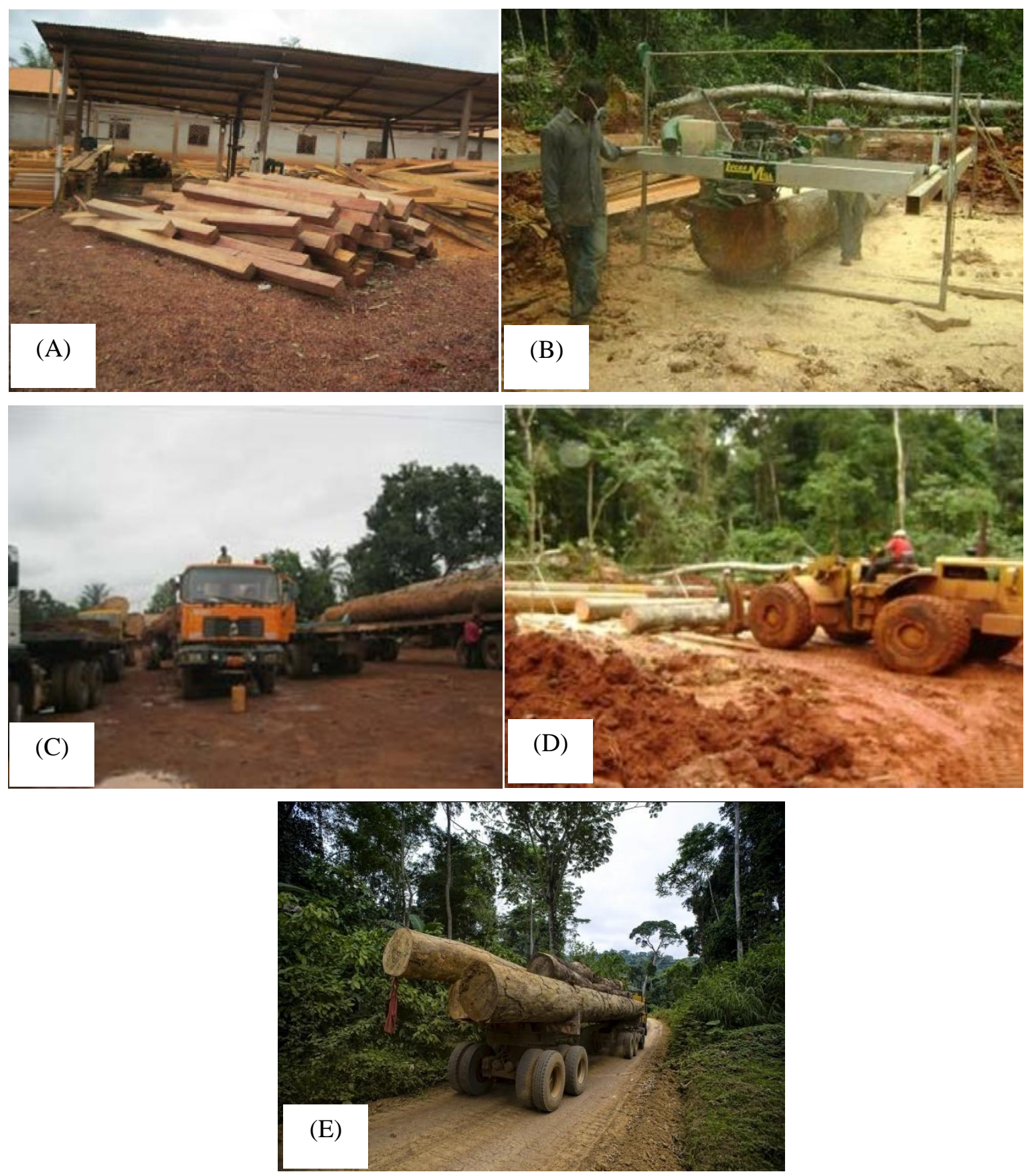

Plate 2. Industrial Wood Exploitation in Dimako (A) sawn plank, (B) modern saw mill for sawing plank, (C) timber loaded on trucks for transportation (D) caterpillar transporting exploited timber from the forest to the semi-processing sites (E) Construction of roads within the Forest for evacuation of timber.

Source: Divisional Delegation of Forestry, Dimako / Field work (2015)

\subsection{Agriculture}

The increase in population entails more demand for food and so more land for crop farming and animal husbandry. Deforestation is inextricably linked to the expansion of agricultural lands. The poor farming methods practiced by the population of Dimako such as the use of bush fires, shifting cultivation and subsistence farming in general has greatly contributed to the rapid destruction of vast forest in rural communities of Dimako (Plate 3). In fact, fire, often goes beyond the expected boundaries, burning more forest surface. In Dimako, the poor implementation of highly productive agricultural practices results to poor yields per surface area cultivated. Therefore, more land is needed 
to produce more food. From this perspective, it can be concluded that the poor agricultural practices and farming methods used by the farmers in Dimako have greatly contributed to rapid forest degradation in Dimako.

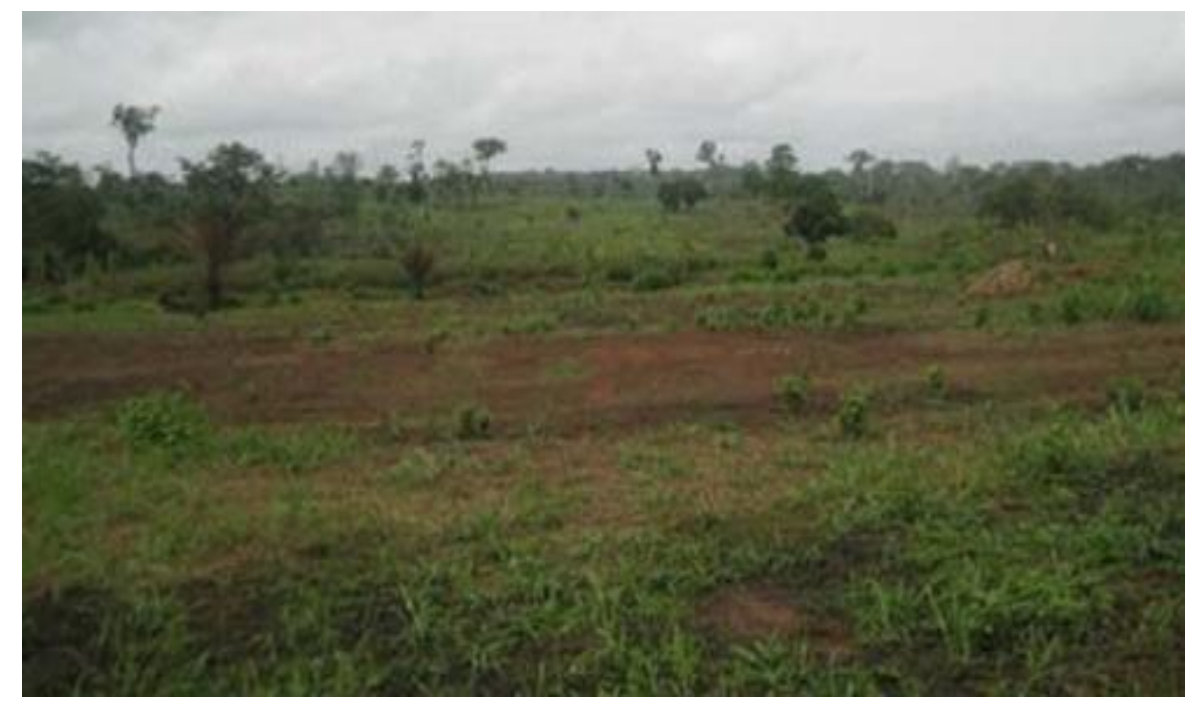

Plate 3. Expansion of Agriculture in Deforested Areas in Dimako.

Source: Divisional Delegation of Forestry, Dimako / Field work (2015)

\subsection{Poverty}

Poverty is one of the major causes of forest exploitation in Dimako sub division. Ndenecho (2011) noted that in Cameroon, the gap in life opportunities between the rapidly growing cities and the rural areas are huge. While the country side provides food and natural resources for the urban areas, it is in these rural areas where poverty and hunger are most pronounced. The government policy has tended to emphasize urban settlement planning to the relative neglect of rural settlement planning and development despite the fact that urban residents in Cameroon just represent slightly over $40 \%$ of the total population (Ndenecho, 2011). There is the over-reliance of the population on wood for settlement construction. Rural poverty continues to increase because producer prices for cash and food crops declined, resulting to 60\% in rural incomes between 1983 and 1993 (Neba, 1999). This situation caused many inhabitants in the predominantly cash crop producing areas like Dimako sub division to abandon their farms and resolved to subsistence agriculture through slash and burn or forest encroachment. This has affected the surface area of the forest in Dimako leading to forest degradation and deforestation. The above findings are supported by those of UNEP (2011) who highlighted the role of poverty in environmental degradation and proposed pathways to sustainable development and poverty eradication.

\section{Consequences of Forest Degradation in Dimako}

Deforestation as a process has a lot of negative consequences on the environment in terms of biodiversity loss, exposing the top soil to agents of erosion, and siltation of rivers and streams. Respondents were then asked their opinion on the various constraints facing the forest in Dimako. About $60 \%$ of the respondents were of the opinion that lost of biodiversity is the dominant environmental constraint facing the forest in Dimako. Also, the illegal cutting down of trees represent $28 \%$, soil infertility $7 \%$ and soil degradation $3.9 \%$. All these factors contribute to environmental degradation in Dimako and its neighbourhoods.

\subsection{Ecological Effects of Forest Degradation in Dimako}

Respondents were sampled on the environmental impacts of deforestation faced by the population of Dimako sub division. Obviously, due to forest degradation in this locality, the environment has suffered so many damages due to man's activities and the people interviewed had diverse views on the environmental impacts faced by the population of Dimako as a result of deforestation and forest degradation. From the survey, soil degradation is the dominant environmental impact and represents about 55\%. This soil degradation is highly witnessed in this area. This results principally from the intense forest exploitation which results to bare land surfaced thus exposing the land to agents of erosion. The lost of biodiversity represents about $21 \%$, followed by low agricultural yields which 
result from the negative environmental impacts caused by deforestation. Lastly, $9.6 \%$ of the population opted for an increase in temperatures. From this perspective, it is clear that intense forest exploitation is very detrimental to the environment in many ways. Forest degradation caused by the destruction of tree cover in Dimako and its environs occurs when the forest resources are indiscriminately exploited. The forest no longer makes valuable contribution to the environment or to the people who depend upon them. Tropical forest destruction threatens the native people whose culture and physical survival depends on the forest. Thus, the environmental impact of degradation increases runoff, soil erosion, pollution of water resources and loss of biodiversity both the plant and animal species. The population is also deprived of fruits from the tropical forest which in some cases are used as spices for cooking (for example, Njangsang and bush mangoes). Since most of the trees are being destroyed, the people are facing difficulties in finding valuable species. Valuable tree species of economic value such as mahogany, iroko, moabi and sapelli are near extinct in this locality. There is therefore great need for the effective and efficient protection of the few remaining species, if not, the inhabitants would suffer from the lack of building materials. Moreover, there has been a gradual loss of wildlife in Dimako. Examples include chimpanzees, bush pigs, pangolin and monkeys. Some animals have also migrated to distant land and penetrated very deep in the forest due to vast forest destruction. For example, gorillas and chimpanzees which were once commonly seen in the nearby forest during the early 1960s and 1970s are rarely seen nowadays by the youths of today. These species have gone deep into the forest due to the devastating effects of deforestation and habitat loss. Consequently, deforestation has led to the extinction or endangerment of plant and animal species. Many plant species which served medicinal purposes for the local people have disappeared and even when found it is only in the deep forest farther away from the areas they used to be in the past. Therefore, the over exploitation of the forest in Dimako has led to endangerment and possible extinction of particular plant species (Table 2). As such, these plant species have been banned from exploited.

Table2. Species of Trees Threatened with Extinction and Banned from Exploitation in Dimako Sub Division

\begin{tabular}{|l|l|c|}
\hline \multicolumn{1}{|c|}{ Vernacular / local name } & \multicolumn{1}{|c|}{ Scientific name } & Density (tree / ha) \\
\hline Doussie (Red) & Afzelia bipindesis & 0.04 \\
\hline Moabi & Baillonella toxisperma & 0.02 \\
\hline Kossipo & Entrandrophragma condollei & 0.05 \\
\hline Paro Rosa & Swartzia fistuloides & 0.01 \\
\hline Tiama & Entadrophragma congolensis & 0.05 \\
\hline Acajou (Bassam) & Khaya ivorensis & 0.05 \\
\hline Azobe & Lophira alata & 0.02 \\
\hline Sipo & Entadrophragma utile & 0.02 \\
\hline Mukulungu & Autranella congolensis & 0.01 \\
\hline Acajou (Blanc) & Khaya anthoterri & 0.06 \\
\hline Fromager & Ceiba pentandra & 0.76 \\
\hline
\end{tabular}

Source: $M I N F O F$ (2006)

\subsection{Reduced Soil Fertility and Increased Erosion}

The poor agricultural method of slash-and-burn improves soil fertility only for a relatively shorter period of time through ash derived from burning which increases the potash and phosphorus content in the soil. But in the long run, soil micro-organisms and bacteria which help to enrich the soil are destroyed which automatically affects the rate of decomposition from dead organic matter. Since decomposition is low to enrich the soil, reduction in crop yield is the resultant consequence. The exposure of the soil to atmospheric processes caused by tree removal necessitates increased runoff and devastating effect of soil erosion. Greater proportion of the marginal lands found in Dimako and its environs have and are still suffering from erosion due to the effects of deforestation.

\subsection{Silting of Rivers and Flood Plain Effect}

When the forest is removed, the total amount of surface water that flows into rivers and streams actually increases. The flow is no longer regulated by the forest and vegetation cover. Flooding of the surrounding lowlands may be an inevitable outcome of this process of deforestation and vegetation degradation. Runoff caused by deforestation has the potential of causing a river or stream silting and consequently flooding. Also, because of the silting of streams, many aquatic species are negatively 
affected or at times destroyed. This further leads to the extinction of some species. This process of silting of streams by the soil or other materials is known as "eutrophication". Also, runoff which washes away the top soil and other materials in certain stream channels causes serious environmental problems as the streams have witnessed a change in their nature and character. The streams for instance increase in size and volume during the rainy season and reduce in size during the dry season. In another vein, many rivers which served as sources of water and other domestic uses in Dimako are now drying up due to exposure and direct sunray effects leading to rapid and intense evaporation especially during the dry season. From this perspective, it is clear that during the dry season the inhabitants of Dimako usually face serious water shortages whereby many streams and rivers dry up thus making the inhabitants to trek for many kilometres in search of drinking water.

\section{Mitigation of the Effects of Deforestation in Dimako Sub Division}

The respondents were asked to present their opinions on the various strategies used to mitigate the effects of deforestation in Dimako sub division. The following responses were obtained. To make efficient recommendations on the proper management of the forest so as to ensure the sustainability of the forest, the respondents had diverse views on the matter. It was revealed that $63.5 \%$ of the respondents were of the view that reafforestation and afforestation practices should be applied so as to ensure sustainability of the forest. This will regenerate the area that has been degraded. Thus, it is clear that through the implementation of these methods, the degraded forest will gradually be revived. Also, about $34 \%$ of the respondents were in favour of other methods such as obtaining licenses from the government before any forest exploitation, curbing illegal exploitation of the forest and implementing efficient farming methods. If all these are put in place with the main goal to restore the distorted forest, then the sustainability of the forest will be guaranteed. Therefore, putting these methods in place will mean preserving and reviving the forest for the future generations. It therefore follows that methods like afforestation and reafforetation will eventually lead to heightened environmental preservation and restoration of the degraded forest in Dimako. These findings are in line with those of FAO (2012), Field (2010), Elliot et al., (2006), Miller (1994) and Owen \& Chiras (1990) who proposed strategies for mitigation of the impacts of human activities on forest activities at the global and regional levels.

\subsection{Stakeholders of Forest Management in Dimako Sub Division}

It was also important to assess the responsibility of each party (stakeholder) in managing the forest in Dimako sub division. As a result, the following responses were obtained. From the survey, it was revealed that about $48 \%$ of the respondents were in support of the fact that it is the council that has the preponderance or main responsibility to manage the forest mainly because they are in the forefront and the council represents the local authorities in this locality. Therefore, the council is in the best place to manage the forest well and to implement sustainable methods. Also, about $17 \%$ of the respondents attributed forest management in this area to the government. From this perspective, they hold the government responsible for forest degradation in Dimako because they say that it is the government that issues exploitation permits without the approval at times of the local authorities and even the local inhabitants mainly because they are the ones in place, and thus are exposed to the negative impacts of deforestation. Therefore, full government-council cum local inhabitant relationship will foster the sustainability of the forest in Dimako. Also, the local inhabitants are also responsible for their forest management and represents 34\%. It revealed that the respondents largely attributed the rapid forest degradation to the local inhabitants. From this perspective, local population also play a predominant role in forest management as no one can better manage it than the local inhabitants themselves. As such, their contribution to sustainability is highly requested for posterity and as such the effort of one another will be good for the overall sustainability of the forest. It therefore follows that forest degradation is not a one man's issue but the entire society is concerned. This is supported by the views of the World Bank (1996). Therefore efforts should be carried out jointly to preserve the forest of Dimako sub division.

\section{VERIFICATION OF HYPOTHESES}

Two hypotheses were postulated to guide this study. The first hypothesis stated that "there exist a direct relationship between deforestation and the rate of population growth". The second hypothesis stated that deforestation is a function of the intensification of human activities". The rates of the above stated hypotheses as a product of deforestation were carefully investigated so that the researchers could really trace the main causes of deforestation in Dimako. 
From the findings, annual crops and fallows occupy the greatest portion of total surface area which involved 475ha in 1999 and increased to 487.5ha in 2001, and the trend has continued till present. Compared to other fact, this stands out as a major contributing factor due to shifting cultivation. The high cultivation of annual crops and fallows is as a result of population increase due to high birth rate in this locality, as already explained in this study. From this, vast expanses of land are being cleared off to permit the cultivation of crops, thus resulting to deforestation. From this perspective, it is clear that there exist a direct relationship between deforestation and the rate of population growth in Dimako sub division. As a result, hypothesis one of the study which states that there exist a direct relationship between deforestation and population growth in Dimako sub division is accepted. It therefore implies that due to high population growth as a result of high birth rate, there is eventually deforestation. This is mainly because as the population increases so too the needs for land increase. The land is needed for settlement and agricultural purposes to feed the ever increasing population. Thus, it is evident that population growth and deforestation in Dimako are intricately interrelated.

Secondly, deforestation in Dimako is a function of the intensification of human activities. Findings revealed that industrial wood exploitation which constitutes about 53\% is the predominant human activity and the main cause of forest degradation in Dimako sub division. This is very true due to the fact that industrial wood exploitation implies massive cutting down of trees over very large expands of land as compared to other human activities like wood collection which represents only $5.8 \%$. This is mainly because the quantity of wood collected by the people for their daily usage is very minimal but on another dimension wood collection becomes a problem when it is collected in large quantities for sale in the neighbouring urban centres like in Bertoua, where the demand for wood as a source of fuel is very high. Lumbering is very detrimental to the forest and it constitutes $19.2 \%$ while farming which is the principal activity in this area constitutes only $17.3 \%$. Thus, from these explanations, it is clear to conclude that if not of industrial wood exploitation the forest in Dimako would not have witnessed intensive forest degradation and consequently the rate of deforestation nowadays.

\section{CONCLuSION}

The complexity of forest exploitation indicates the need to re-examine the forest development skills needed to deal with the problems of unsustainable management of the forest. Professionals need to bring in alternative methods of exploiting forest products and improve agricultural techniques. From this perspective, forest exploitation has seriously developed Dimako and its neighbourhoods but the environmental impacts are very damaging to the flora and fauna, thus resulting to a severe blow on the biodiversity. The general effect of deforestation can be seen in biodiversity loss and destabilisation of the ecosystem (flora and fauna). This loss of biodiversity brings alongside a host of many other related effects on the environment, thus affecting the well being of the local inhabitants. The mitigation efforts against deforestation have been carried out by both governmental and nongovernmental organisations to ensure ecological stability through the implementation of some sustainable exploitation measures such as controlled exploitation in terms of size and age of the trees, reafforestation and afforestation. These also include laws concerning forest conservation such as Law No. 94/01 of January 1994 and also the creation of awareness to the local people on sustainable exploitation techniques. A fundamental dimension of the overall strategy is that the inhabitants concerned must be organised and engaged in all conservation measures, taking into consideration the fact that the success of their conservation will largely depend on the ability to reconcile the objective of conservation together with the need of the exploiters and the local community. In Dimako, every conservation method from the local level to the national level has been made but the goal of sustainable forest exploitation has not been achieved. This is because the extent of exploitation of forest resources far surpasses the amount of conservation carried out in Dimako. Furthermore, forest conservation is not a one man's issue but the problem of the entire population. From this perspective, each and every one should put their contribution in the building of a sustainable forest exploitation strategy which will benefit the present population as well as the future generations. Let us stand as one to protect the forest because by so doing, we are preserving the environment for our generations and the future generations. Thus, this slogan is proposed to be used in every locality to effectively combat forest degradation "NO to excessive forest exploitation and YES to a proper preservation of our forest; our future is in our hands". In order to attain this slogan, the following recommendations are proposed to be implemented effectively. 


\section{RECOMMENDATIONS}

The forest has inestimable wealth to enhance human survival. It has always been part of the existence of human beings. Due to human greed, the forest has undergone serious damages and thus has led to environmental degradation. From the research findings of this study, it should be understood clearly that forest and forest resources play the greatest role to the economy of the rural population, providing food, building materials, recreational sites and pharmaceutical products. In another perspective, forest exploitation in an unsustainable rate has led to depletion of these resources. It is therefore necessary for the government through the various institutions including the Ministry of Forestry and Wild Life, and the Ministry of Environment, Nature Protection and Sustainable Development at the national, regional and divisional levels to carry out some mitigation measures in protecting both the national and local forests. From this perspective, the following recommendations are suggested to effectively reduce the environmental impacts of deforestation in Dimako sub division. The forest provides a lot of benefits to people ranging from economic, social, cultural and religious. This has led to indiscriminate forest exploitation for its timber and non-timber forest products. But too much exploitation might lead to future calamities like destruction of natural ecosystems and watersheds, extinction of plant and animal species which are very important for the survival of future generations. The community should be educated and sensitized on the importance of a forest reserve and the purpose of a forest reserve which include: maintenance of natural ecosystem for the better functioning of the planet and its inhabitants and the preservation of important plant and animal species for future consumption. Education and sensitisation campaigns should be made through private organisations and even government officials on the people to create awareness on the importance of forest conservation on the environment and the adverse effects when the forest undergoes damages caused by man. Timber exploitation should be prohibited or levied high export taxes in order to discourage massive timber exploitation to different countries so as to reduce pressure on the forest. Also, licences should be issued to timber exploiters and forest authorities should be established to guard the forest from any defaulters who are very rampant in Dimako sub division. The defaulters should also be punished by the government. During exploitation, authorities should also make sure that only mature trees are felled while the young ones remain to regenerate the forest. Exploitation companies which are largely responsible for forest degradation should be mounted pressure to plant trees wherever they have exploited. A plan of action should be put in place whereby whenever the exploitation companies cut one tree they should plant five younger trees. This will effectively promote forest regeneration at a very fast rate, thus reducing the environmental impacts of forest degradation and deforestation in Dimako. The government and cooperative societies should provide farmers with chemical fertilizers to help produce more food without cultivating on large expands of land, thus reducing the cutting down of trees and also reduce the rate of shifting cultivation, which is one of the main causes of deforestation in Dimako sub division. Also, food crop production should be encouraged and cash crop production limited since cash crop farming leads to semi permanent lost of farmland, and also a major driver of forest degradation through continuous expansion of farms in forested areas. Concerning communal forest, the forest law should prescribe procedures for acquiring and disposal of forest products and also a decree to be enacted to implement the forestry laws. Lastly, to preserve the few remaining forest, the government should create parks and reserves so as to avoid encroachment in anyway so that at least the remaining forest species could be preserved for future generations.

\section{REFERENCES}

Angelsen, A. and Kaimonitz, D. (1999). Rethinking the Causes of Deforestation. Lesson From Economic Model. The World Bank Research Observer, 14.1 Oxford University Press, pp. 73-98.

Bannon, I. and Collier, P. (2003). Natural Resource and Violent Conflict: Option and Actions. World Bank 1818H Street Washington, DC, USA.

Barraclough, S. and Ghimire, K. B. (2000). Agricultural Expansion and Tropical Deforestation. Earthscan.

Bjorn, L. (2001). The Sceptical Environment: Measuring the Real State of the World. The Pitt Building, Trumpington Street, Cambridge, UK.

Brown, D., (2002). Forestry as an Entry-Point to Governance Reform: The Case of Cameroon. Overseas Development Institute.

Butler, R. A. (1994). Human Threats to Rainforest Economic Restructuring. Mangabay.com A Place out of Time. Tropical Rainforest and the Perils they face. Retrieved May, 13, 2009. 
The Socio-Economic Importance of Forest Exploitation and Environmental Impacts of the Consequent Deforestation in Dimako, East Region of Cameroon

Butler, R., A. (2006). Population Impact and Poverty on Rainforest. Mangabay.com A Place out of Time. Tropical Rainforest and the Perils they face. Retrieved May, 13, 2009.

Cabinet NECT (2011). Etude d'Impact Environmental Sommair du projet d'exploitation de la foret. Communal de Dimako, rapport final, 111 pages.

CANADEI (2010). Plan de development de Dimako 2010 - 2014. 90 pages.

Chakravarty, S., S. K. Ghosh, C. P. Suresh, A. N. Dey and G. Shukla (2012). Deforestation: Causes, Effects and Control Strategies, Global Perspectives on Sustainable Forest Management, Dr. Dr. Clement A. Okia (Ed.), ISBN: 978-953-51-0569-5, InTech, Available from: http://www.intechopen.com/books/global-perspectives-on-sustainable-forestmanagement/deforestation-causes-effects-and-control-strategies

Dindi, (2011). Statistical Confirmation of Indirect Land Use Changes in Brazilian Amazon. Env. Press, Review, Britain.

Delénè, V., Mesmin, T. and Fogwe Z. (2009). Forest Exploitation in Cameroon: Stakes and Current Challenges. In Lambi, C.M. (Editor), Cameroon: A Country At Crises Crossroads An Anthology in the Social Sciences, NAB Ventures, Bamenda, Cameroon. pp. 223-236, ISBN: 9956-420-18-2.

Elliot, S.D., Blackesley and Harwick (2006). Restoring Tropical Forest. A Practical Guide. Kew Publication, London.

FAO (1997). Pan-Tropical Survey of Forest Cover Changes 1980 to 2000. Forest Resources Assessment. FAO, Rome, Italy.

FAO (1997). State of the World's Forests 1997. Rome. www.fao.org/docrep/w4345e/w4345e00.htm.

FAO (2000). Global Forest Resources Assessment 2000. FAO Forestry Paper 140, Rome.

FAO (2003). State of the World's Forests 2003. Rome. ftp.fao.org/docrep/fao/005/y7581e/.

FAO (2005). Global Forest Resources Assessment 2005 - Progress Towards Sustainable Forest Management. FAO Forestry Paper No. 147. Rome. www.fao.org/docrep/008/ a 0400e /a $0400 \mathrm{e} 00 . \mathrm{htm}$.

FAO (2006). Global Forest Resources Assessment 2005. FAO Forestry Paper 147, Rome.

FAO (2007). State of the World's Forests 2007. Rome. www.fao.org/docrep/009/a0773e /a0773 e00.htm.

FAO (2010). Global Forest Resources Assessment 2010 - Main Report. FAO Forestry Paper No. 163. Rome. www.fao.org/docrep/013/i1757e/i1757e00.htm.

FAO (2011). Forests for Improved Nutrition and Food Security. Rome. www.fao.org/forestry/ 2797602c09ef000fa99932eefa37c22f76a055.pdf.

FAO (2012). State of the World Forest 2012. Rome, 2012 ISBN 978-92-5-107292-9

Field, F. (2010) How Can you Save the Rainforest. CANADE Retrieved on October, 8, 2006.

Global Deforestation (2006). Global Change Curriculum. University of Michigan Global Change Programme, January 4, 2006.

Lambi, C.M. (2010). The Environment and Development Frontier in Sub-Saharan Africa: Some Global Lessons. NAB Ventures, Bamenda, Cameroon.

López, C. \& Shanley, P. (Eds) (2004). Riches of the Forest: For Health, Life and Spirit in Africa. Centre for International Forestry Research. Indonesia. E-mail: cifor@cgiar.org; Website: www.cifor.cgiar.org.

Marcoux, A. (2002). Population and Deforestation. SD Dimensions. Sustainable Development, Food and Agricultural Organisation of the United Nations. Rome.

Mesmin, T. and Fogwe, Z. (2009). Ecotourism in Protected Areas of Cameroon: Trends, Problems and Prospects. In Lambi, C.M. (Editor), Cameroon: A Country At Crises Crossroads An Anthology in the Social Sciences, NAB Ventures, Bamenda, Cameroon. pp. 197-222, ISBN: 9956-420-18-2.

Mesmin, T., Fogwe, Z., and Kengne, F. (2009). Cameroon as a Country of Under-Exploited Touristic Potentials. In Lambi, C.M. (Editor), Cameroon: A Country At Crises Crossroads An Anthology in the Social Sciences, NAB Ventures, Bamenda, Cameroon. pp. 185-196, ISBN: 9956-420-18-2. 
Miller, G.T. Jr. (1994). Sustaining the Earth: An Integrated Approach. Wadsworth Publishing Company, Belmont California, USA.

MINEF (Ministere de L'Environment et Des Forets (1995). Projet Api de Dimako, Generaliter sur l'amenagement des forets de production de la province de l'Est, 123pages.

Neba, A.S. (1999): Modern Geography of the Republic of Cameroon. Third Edition. Neba Publishers, Bamenda Cameroon / Camden, New Jersey, USA.

Owen, O.S. and Chiras, D.D. (1990). Natural Resource Conservation: An Ecological Approach. Fifth Edition, Macmillan Publishing Company, $3^{\text {rd }}$ Avenue, New York.

Sunderlin, W.D., Angelsen, A., Belcher, B., Burgers, P., Nasi, R., Santoso, L., \& Wunder, S. (2005). Livelihoods, Forests, and Conservation in Developing Countries: An Overview. World Development Vol. 33, No. 9, pp. 1383-1402, 2005. Elsevier Ltd. Great Britain.

UNEP (2011). Towards a green economy: pathways to sustainable development and poverty eradication. Nairobi. www.unep.org/greeneconomy/portals/88/documents/ger/ger_final_ dec_ 2011 /green\%20economyreport_final_dec2011.pdf.

Van Kooten, G. C. and Bulte, E. H. (2000). The Economics of Nature: Managing Biological Assets. Blackwells.

Williams, M. (2003). Deforesting the Earth. University of Chicago Press, Chicago ISBN 0-22689926-8.

World Bank (1996). Towards Environmentally Sustainable Development in Sub Saharan Africa. The World Bank Agenda: The World Bank, Washington, D.C., USA.

\section{AUTHORS' BIOGRAPHY}

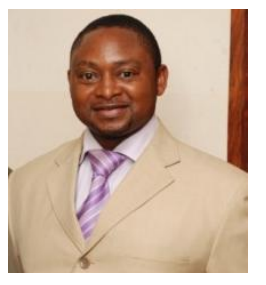

Dr. Robert Njilla Mengnjo Ngalim, holds a Bachelor of Science (B.Sc. Hons) Degree, Master of Science (M.Sc.) Degree in Geography with specialisation in Environment and Natural Resource Management and a Doctor of Philosophy (Ph.D.) Degree in Geography with specialisation in Natural Resources Management from the University of Buea, Cameroon. Dr. Njilla is a Lecturer / Consultant on Specified Assignment, Department of Development Studies, Pan African Institute for Development West Africa (PAID-WA), Buea. He is also the Coordinator for Research in the same Institution. Dr. Njilla has published several articles in peer-reviewed learned academic journals in Cameroon and abroad. His research interest include aspects such as Applied Physical Geography, Hydrology and Water Resources Management, Geography of Resources and Environmental management, Contemporary Issues in the $21^{\text {st }}$ Century with particular interest in Climate Change related impacts, and Modern Techniques in Geographic Research and Data Analysis, amongst others. Dr. Njilla is also a Freelance Researcher and Consultant on Environmental and Developmental Issues affecting humankind today.

Mr. Djou Edgard, holds a Bachelor of Science (B.Sc. Hons) Degree from the University of Buea, Cameroon and is currently a studying for the Master of Science (M.Sc.) Degree in Geography in the same institution. His research areas include natural resources management, geomorphology and applied physical geography. 